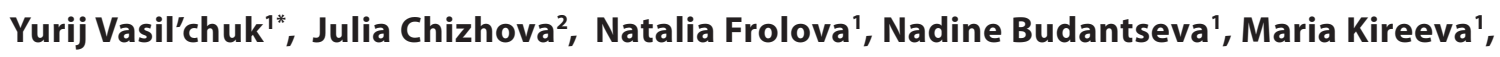
Alexander Oleynikov' ${ }^{\text {, Igor Tokarev }}{ }^{3}$, Ekaterina Rets', Alla Vasil'chuk'

${ }^{1}$ Lomonosov Moscow State University, Faculty of Geography, Moscow, Russia

${ }^{2}$ Institute of Geology of Ore Deposits, Petrography, Mineralogy, and Geochemistry (IGEM RAS), Moscow, Russia

${ }^{3}$ The Centre for X-ray Diffraction Studies, Research park at St. Petersburg University, St. Petersburg, Russia

*Corresponding author: vasilch_geo@mail.ru

\section{A VARIATION OF STABLE ISOTOPE COMPOSITION OF SNOW WITH ALTITUDE ON THE ELBRUS MOUNTAIN, CENTRAL CAUCASUS}

\begin{abstract}
This study aims to analyze the stable isotope composition of the snow cover of the Elbrus Mountain - the highest mountain in Europe. Snow sampled in the middle accumulation period in January 2017, February 2016, January 2001 and during snowmelt in July 1998 and August 2009. Snow sampled at the south slope of Mt. Elbrus at different elevations, and the total altitude range is approximately $1700 \mathrm{~m}$. A significant altitude effect in fresh snow precipitation was determined in February 2001 with gradient $-1.3 \% 0 \delta^{18} \mathrm{O} / 100 \mathrm{~m}\left(-11.1 \% 0 \delta^{2} \mathrm{H} / 100 \mathrm{~m}\right)$ at 3100-3900 $\mathrm{m}$ a.s.l. and inverse altitude effect in February 2016 with gradient $+1.04 \% 0 \delta^{18} \mathrm{O} / 100 \mathrm{~m}\left(+8.7 \% 0 \delta^{2} \mathrm{H} / 100 \mathrm{~m}\right)$ at 3064-3836 m a.s.l. There is no obvious altitude effect of the $\delta^{2} \mathrm{H}$ and $\delta^{18} \mathrm{O}$ values in snow at the Elbrus slope in 2017, except for the height range 2256-3716 $\mathrm{m}$ a.s.l., where altitudinal effect of $\delta^{18} \mathrm{O}$ values was roughly $-0.32 \% 0 / 100 \mathrm{~m}$. The $\delta^{18} \mathrm{O}$ values in the winter snowpack in some cases decrease with increasing altitude, but sometimes are not indicating a temperature-altitude effect. Post-depositional processes cause isotopic changes, which can result from drifting, evaporation, sublimation, and ablation. The study of altitude effect in snow is important for understanding the processes of snow-ice and snow-meltwater transformation and the snow/ice potential to provide paleo-environmental data.
\end{abstract}

KEY WORDS: stable isotopes, spatial variability, snow cover on glaciers, high altitude, Caucasus

CITATION: Yurij Vasil'chuk, Julia Chizhova, Natalia Frolova, Nadine Budantseva, Maria Kireeva, Alexander Oleynikov, Igor Tokarev, Ekaterina Rets, Alla Vasil'chuk (2020) A variation of stable isotope composition of snow with altitude on the Elbrus Mountain, Central Caucasus. Geography, Environment, Sustainability, Vol.13, No 1, p. 172-182

DOI-10.24057/2071-9388-2018-22

\section{INTRODUCTION}

For all studies that require information about the isotopic composition of the snowpack in a catchment, detailed information on the spatial and temporal variability of the isotopic content of snow is valuable. The water input in snow-dominated watershed for residence time analysis, end member mixing analysis or the detection of source water contribution requires a detailed understanding of the effects of factors that modify the isotopic composition of snow cover.

During orographic lift of air mass, the heavier water molecules condense at first, i.e. the precipitation is isotopically enriched, and the cloud moisture is subsequently depleted due to continuous precipitation under equilibrium fractionation.

Depletion of the isotopic composition of precipitation with elevation is the "altitude isotope effect" - the altitude isotope effect in precipitation well-known since the Dansgaard (1964) research. The altitude effect is temperature-related because the condensation is caused by the temperature drop due to the increasing altitude. Due to the decreasing pressure with increasing altitude, a larger temperature decrease is required to reach the saturated water vapor pressure than for isobaric condensation. Moser and Stichler (1970) observed altitudinal isotope effect in fresh snow at the Kitzsteinhorn in Austrian Alps. An elevation gradient for $\delta^{18} \mathrm{O}$ values between is -0.6 and $-1.0 \%$ per 100 in high mountains in the snow was determined (Niewodniczanski et al. 1981). However, there was in a wide range of isotope values with small-scale inverse gradient and thus only partly attributable to a linear elevation gradient. These variations explained by conditions during snowfall and after snow deposition, such as wind drift and fractionation by melting processes, as well as orographic and climatic features of the studied areas (Niewodniczanski et al. 1981). For the fresh snow in the Canadian Rocky Mountains, elevation gradients range from -0.3 to $+1.8 \%$ o per 100 $\mathrm{m}$, depending on snowfall and accumulation conditions (Moran et al. 2007).

In contrast to the altitude isotope effect in fresh snow, the isotopic composition of an entire snowpack is more complex (Moser and Stichler 1974). The snowpack is altered by sublimation, evaporation, metamorphism of snow crystals, percolating of meltwater and isotopically enriched precipitation, especially in temperate climatic conditions (Judy et al. 1970; Ambach et al. 1972; Stichler et al. 2001; Sokratov and Golubev 2009). These processes may conceal the altitudinal effect in fresh snow and result in inverse gradients (Moser and Stichler 1970). In some cases, there was no significant relation between the isotopic signature of the entire snowpack and elevation (Raben and Theakstone 1994; Kang et al. 2002; Königer et al. 2008).

Dietermann and Weiler (2013) observed only a limited altitude isotope effect in Swiss Alps. The altitudinal effect for $\delta^{2} \mathrm{H}$ values at the south-facing slopes ranged from -6.2 to $+2.6 \%$ / $/ 100 \mathrm{~m}$ with a wide variability for the individual samples. These results confirm the influence of melting processes altering the mean isotopic composition of snow cover. The north-facing slope of this catchment is a steep av- 
alanche-prone slope popular for mountain skiing. These factors likely lead to snow mixing and disturbance of the altitude isotopic effect (Dietermann and Weiler 2013).

We have found the altitudinal effect on $\delta^{18} \mathrm{O}$ and $\delta^{2} \mathrm{H}$ values of fresh snow on the southern slope of Elbrus in January 2001, decreasing with increasing altitude (Vasil'chuk and Chizhova 2010). The of snow becomes more and more depleted in ${ }^{18} \mathrm{O}$ and ${ }^{2} \mathrm{H}$ content at higher elevations. In the range of 3100-3400 $\mathrm{m}$ a.s.l., the gradients are $-2.4 \%$ / $100 \mathrm{~m}$ for $\Delta \delta^{18} \mathrm{O}$ and $-20 \%$ for $\Delta \delta^{2} H$ values, and at altitudes of 3400-3900 m they are $-0.6 / 100 \mathrm{~m}$ for $\Delta \delta^{18} \mathrm{O}$ and $-6 \%$ for $\Delta \delta^{2} H$ values. We found a decreasing $d$-excess values in snow at 3100 to 3400 $\mathrm{m}$ a.s.l. We associated high gradients at altitudes from 3100 to $3400 \mathrm{~m}$ with intensive washing out of the air mass and isotopic depletion during precipitation. However, if we assume, based on the isotope data, the decrease of $\delta^{18} \mathrm{O}$ values from -17 to $-29 \%$ in snow with increasing altitude from 3100 to $3400 \mathrm{~m}$ due to progressive precipitation, the decreasing of $\mathrm{d}$-excess in this snow could not be explained.

The progressive rainout process based on the Rayleigh fractionation/condensation model predicts increasing d-excess values in the latest stages of precipitation. Also, the equilibrium Reyleigh condensation model including the isotopic kinetic effect (Jouzel and Merlivat 1984) as well as isotopic model including mixed cloud processes (Ciais and Jouzel 1994) predict relatively high values of d-excess.

In many cases, the d-excess is found to increase with altitude on the mountain slopes, possibly for a variety of reasons. This issue has not been finally resolved. Hereby, a decreasing $\mathrm{d}$-excess with decreasing $\delta^{18} \mathrm{O}$ values in fresh snow in January 2001 may indicate a very ambiguous formation of the isotopic composition of snow cover on the southern slope of Elbrus.

Recent studies of glaciers of Elbrus are focused on obtaining information about the environmental conditions of ice accumulation, including sources of air masses, atmospheric conditions, and the transformation of snow to ice. The stable isotopes and chemical composition are indicators of the processes involved in atmospheric precipitation.

Observations of recent retreat of the Elbrus glacier system (Vasil'chuk et al. 2006, 2010; Zolotarev and Kharkovets 2010; Holobâcă 2016; Tielidze and Wheate 2017) show significant changes of the glaciers volume and their 'tongues' retreats during the past 100 years, however, there appears to be no signature in the isotopic composition of the glacier ice (Vasil'chuk et al. 2006).

Although most of the incoming moisture to the Elbrus is of Atlantic origin, some air masses drift from the southern deserts. The dust that originates from the foothills of the Djebel Akhdar in eastern Libya and transported to the Caucasus along the eastern Mediterranean coast, Syria and Turkey (Shahgedanova et al. 2013) was found in snowpack of Garabaschi glacier.

Elbrus glacier's ice is paleo-archive, especially at altitudes above $4900 \mathrm{~m}$, where isotope record is undisturbed by the meltwaters due to the absence of melting at this elevation. The isotope records of low-latitude and high-mountain glaciers cores have the potential to provide detailed paleo-environmental proxy record and to prove extremely valuable in producing continuous records of atmospheric chemistry and climate (Thompson et al. 1998, 2006a, 2006b; Tian et al. 2003; Yao et al. 2006). The low-latitude Tibetan cores records, especially Dunde and Dasuopu, are consistent with the local temperature records (Yao et al. 2006), the more northern sites, similar to Dunde, are thought to be more temperature-dominated (e.g., Tian et al. 2003).

In recent years, deep drilling of Elbrus glaciers allowed to obtain $\delta^{18} \mathrm{O}$ and $\delta^{2} \mathrm{H}$ records (Mikhalenko et al. 2015; Kozach- ek et al. 2017). There was no significant correlation between ice core $\delta^{18} \mathrm{O}$ records from the western Elbrus plateau (height $5115 \mathrm{~m}$ a.s.l) with regional temperature, neither with the reanalysis data nor with the data of meteostation (Mikhalenko et al. 2015; Kozachek et al., 2017). At the western Elbrus plateau, the snow accumulation rate is high and moreover, pronounced seasonal variations of $\delta^{18} \mathrm{O}$ and $\delta^{2} \mathrm{H}$ values were noted in the core. In spite of the presence of $\delta^{18} \mathrm{O}$ amplitude in ice core, which could indicate the existence of a $\delta^{18} \mathrm{O}$-temperature relationship, conditions of individual snowfall play an important role. Such conditions include snow mixing by wind and different air masses with different source characteristics affect the precipitation at the base and crest of a mountain.

In this case, the study of the formation of an isotope altitude effect in snow is important for understanding this exclusion of temperature effect in ice. Here, the results of isotope analysis of the snow samples are presented to provide a better understanding of the spatial and temporal features of snow accumulation on Elbrus.

\section{STUDY SITE}

The Caucasus Mountains are located between the Black and the Caspian Seas and generally oriented from east to southeast, with the Greater Caucasus range often considered as the divide between Europe and Asia. The total area of glaciers in the Caucasus is about $1121 \pm 30 \mathrm{~km}^{2}$ (Mikhalenko et al. 2015). Glaciers on the Elbrus Mountain are located in the altitudinal range 2800-5642 $\mathrm{m}$.

The coldest conditions occur above 5200 m a.s.l., where the mean summer air temperature does not exceed $0^{\circ} \mathrm{C}$, while the Elbrus glaciers between 4700 and $4900 \mathrm{~m}$ a.s.l. are prone to surface melting. Snow accumulation measurements from 1985 to 1988 showed total snow accumulation of 400$600 \mathrm{~mm}$ w.e. $\mathrm{a}^{-1}$ with considerable wind-driven snow erosion at the col of Elbrus (5300 $m$ a.s.l.).

The summer atmospheric circulation pattern in the Caucasus is dominated by the subtropical high pressure to the west and the Asian depression to the east. In winter, circulation is affected by the western extension of the Siberian High (Volodicheva 2002). The Caucasus is located in the southern part of the vast Russian Plain and therefore buffeted by the unobstructed passage of cold air masses from the north. High mountain ridges in the southern Caucasus deflect air flowing from the west and southwest. The influence of the free atmosphere on the Elbrus glacier regime is greater than local orographic effects as the glacier accumulation area lies above main ridges.

Most part of the annual precipitation falls in the western and southern parts of the Caucasus. For the southern slope of the Caucasus, the amount of precipitation ranges from $3000-3200 \mathrm{~mm} \mathrm{a}^{-1}$ in the west to $1000 \mathrm{~mm} \mathrm{a}^{-1}$ in the east. The proportion of winter precipitation (October-April) also decreases eastward from more than 50 to $35-40 \%$ for the northern Greater Caucasus and from 60-70 to 50-55\% for the southern slope (Rototaeva et al. 2006). The proportion of solid precipitation increases with altitude and reaches $100 \%$ above 4000-4200 m.

Our research is focused on the southern slope of Elbrus, from the Azau station (2330 $\mathrm{m}$ a.s.l.), along the Garabashi

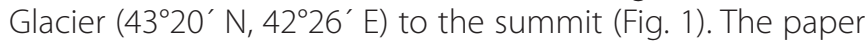
discusses data obtained in 2017, 2016, and, also the data we have obtained in previous years (Vasil'chuk et al., 2006, 2010; Vasil'chuk and Chizhova 2010).

In terms of temperature, the 2015/16 season continued a unique series of warm winters, which began in 2009/10. The temperature anomaly was formed due to warm months at 


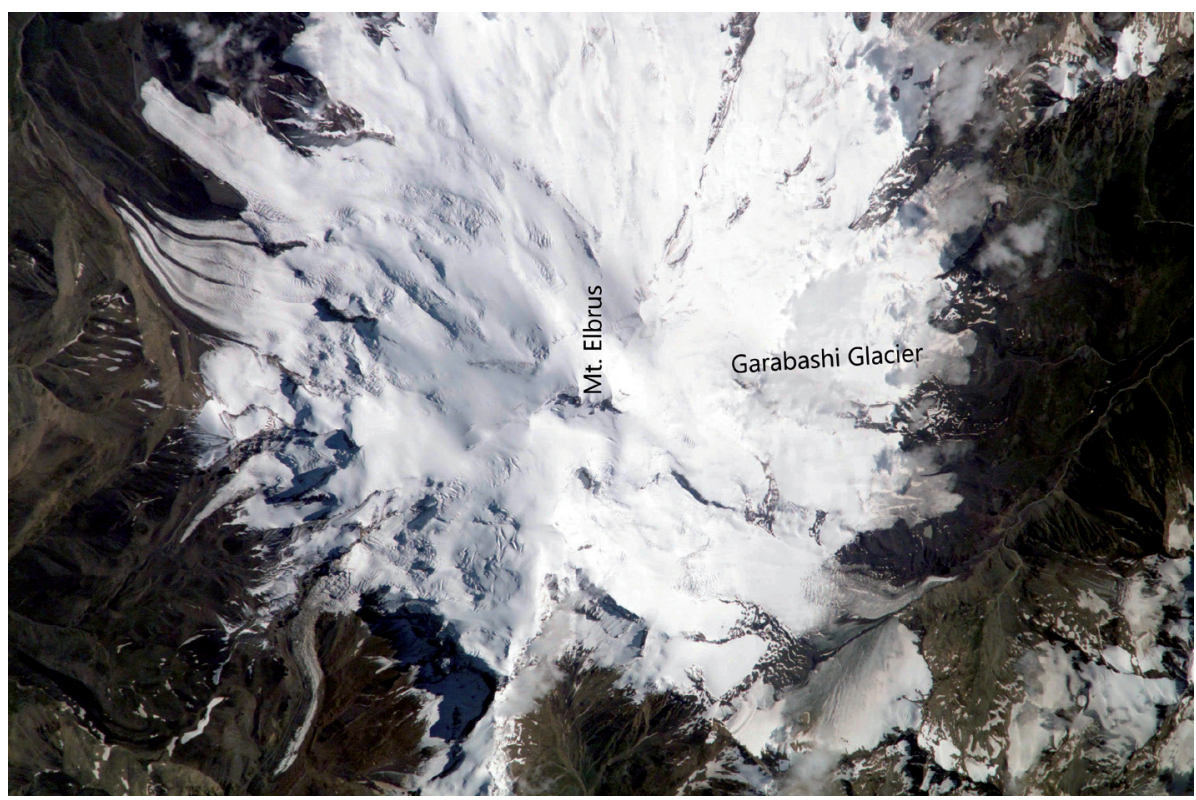

Fig. 1. Space image of Elbrus from SPOT 7 satellite, August 20, 2016

the beginning (November) and the end of winter (February, March). While the traditionally cold months (December, January) were slightly different from the long-year norm.

According to the amount of precipitation, the 2015/16 season was $18 \%$ below normal, and the winter maximum precipitation was recorded in January. During the January snowfall, $101.9 \mathrm{~mm}$ of precipitation fell, which was $36 \%$ of the precipitation of the entire cold period (XI-III). The thickness of the snow at the bottom of the valley during the second decade of January increased from $30 \mathrm{~cm}$ to $72 \mathrm{~cm}$ (weather station Terskol, $2141 \mathrm{~m}$ a.s.l.) and from $59 \mathrm{~cm}$ to $103 \mathrm{~cm}$ (Azau weather station).

Winter 2016/17 was characterized by extremely low precipitation and long periods without precipitation, for example, until January 26, 2017, snow fell only on 26 November. The level of temperature drop with altitude (lapse rate) for the southern slope of Elbrus is concerned to be $0.6^{\circ} \mathrm{C} / 100 \mathrm{~m}$. This lapse rate was determined by comparison of automatic weather station (installed on the western Elbrus plateau at $5115 \mathrm{~m}$ a.s.l.) record with measurements from the nearest meteorological station (Mikhalenko et al. 2015).

\section{METHODS}

Snow was sampled on the south slope of Mt. Elbrus in the middle of the snow accumulation period in January 2017, February 2016, January 2001 and during snowmelt season in July 1998 and August 2009. In 2017, fresh snow was sampled. In 2016, the surface snow (1 Feb) and fresh snow (3 Feb) were sampled, in 2001 and 2009 fresh snow was sampled. During the ablation season of 1998, surface snow was sampled. The sampling was performed at an altitude of about 1700 m (Fig. 2).

Samples of surface snow (from a depth of 0-15 cm) were collected on 1 February 2016 (according to the Terskol weather station, precipitation events were on 28 and 29 January). Samples of fresh snow collected on 3 February 2016 (from a depth of 0-15 cm) represent snow fell on 2 February from morning till evening. According to the Terskol weather station on 2 February, $9 \mathrm{~mm}$ of precipitation fell.

In January 2001 and August 2009, samples of just deposited snow also have been collected within three hours after snowfall at 0-10 cm depth of snow cover. Samples of melted snow were collected at the Garabaschi glacier in July 1998.

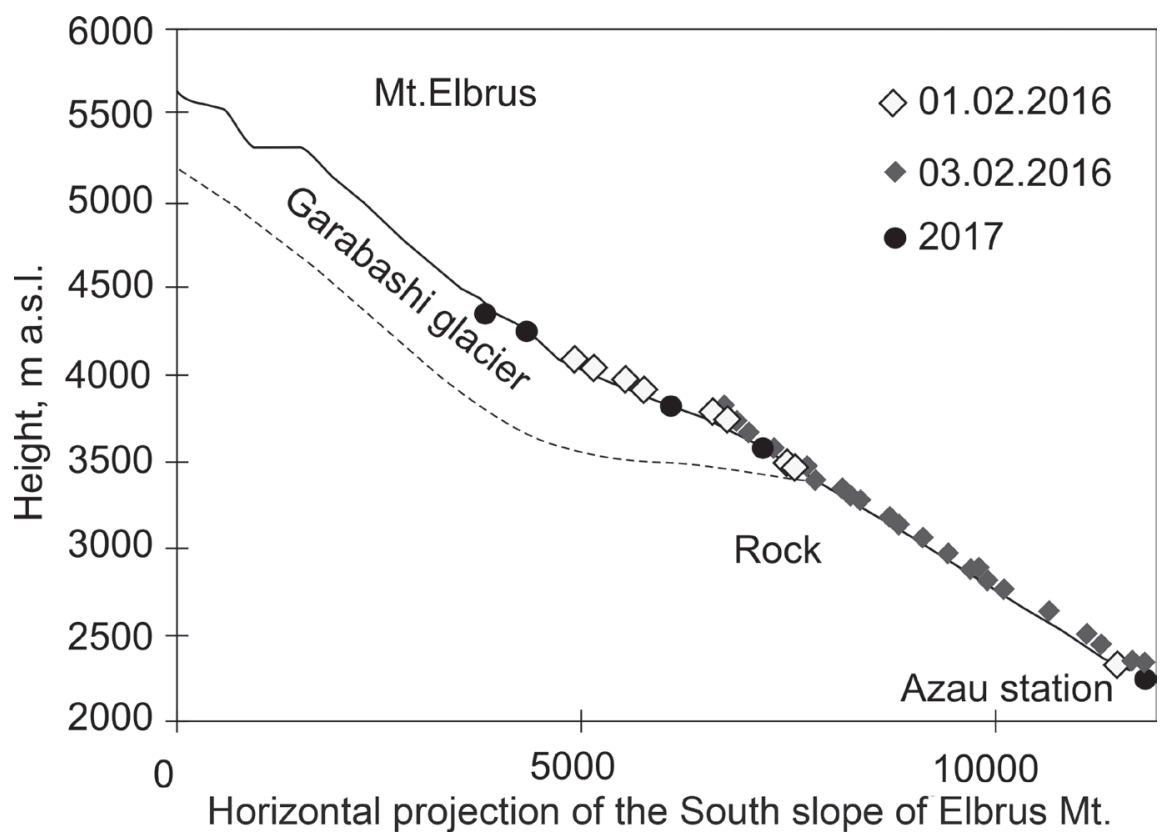

Fig. 2. Sampling profile on the southern slope of Elbrus 
In January 2017, samples of fresh snow were collected within the range of 2300-3800 m a.s.l. On January 27 and 28, in the valley and on the slope of Elbrus, the snow fallen on 26 January was sampled. On January 29 , snow fell in the afternoon and newly deposited snow was sampled on 30 January. All snow samples were taken from 0-10 cm depth of snow cover. In the valley (2332 $\mathrm{m}$ a.s.l.) and at the slope (3345 $\mathrm{m}$ a.s.l.) snow pits had been excavated at $10 \mathrm{~cm}$ intervals.

Isotope ratios in snow of 2016, 2017 and 2009 were measured by a Finnigan Delta-V continuous flow mass spectrometer in Stable Isotope Laboratory of Geographical Department of Lomonosov Moscow State University. Concurrently, isotope composition of snow sampled in 2016, was determined in Saint Petersburg State University Resource center for Geo-Environmental Research and Modeling (GEOMODEL) by Picarro L-2120i. The differences in measured $\delta^{18} \mathrm{O}$ values for the same samples in two laboratories does not exceed $\pm 0.3 \%$. Isotope composition of snow sampled in 2001 and 1998 was measured by W.Papesch in Research center "Arsenal" in Seibersdorf, Austria.

Isotope data are expressed conventionally as $\delta$-notion (\%), representing a deviation in parts per thousand, relating to the isotopic composition of V-SMOW (Vienna Standard
Mean Ocean Water). International standards V-SMOW2, GISP, SLAP2 were used for the calibration. The measurement precision for $\delta^{18} \mathrm{O}$ values is $\pm 0.1 \%$.

\section{RESULTS}

The $\delta^{18} \mathrm{O}-\delta^{2} \mathrm{H}$ ratios for all snow samples (accumulation and melt) are shown in Fig. 3. Most of them are very close to the global meteoric water line.

Altitude isotope effect in fresh winter snow is clearly visible in 2016 at elevation up to 3000 m a.s.l and in 2001 at elevation from 3000 to 4000 m a.s.l (Fig. 4, a). Inverse altitude effect was observed in fresh snow sampled in 2016 above 3000 m a.s.l and in August 2009 (Fig. 4, b).

The values of $d$-excess $\left(d_{\text {exc }}\right)$ in fresh snow have seasonal variations increasing in summer (Table 1). The $d_{\text {exc }}$ values depend on the relative humidity of the air masses at their oceanic origin (Merlivat and Jouzel 1979). The lower $d_{\text {exc }}$ values of precipitation in the northern hemisphere during the summer months correspond with the higher relative air humidity which relates to the SST in the oceanic source regions of the air masses concerned. In the Chinese Tien Shan, high $d_{\text {exc }}$ values were noted during the winter months when pre-

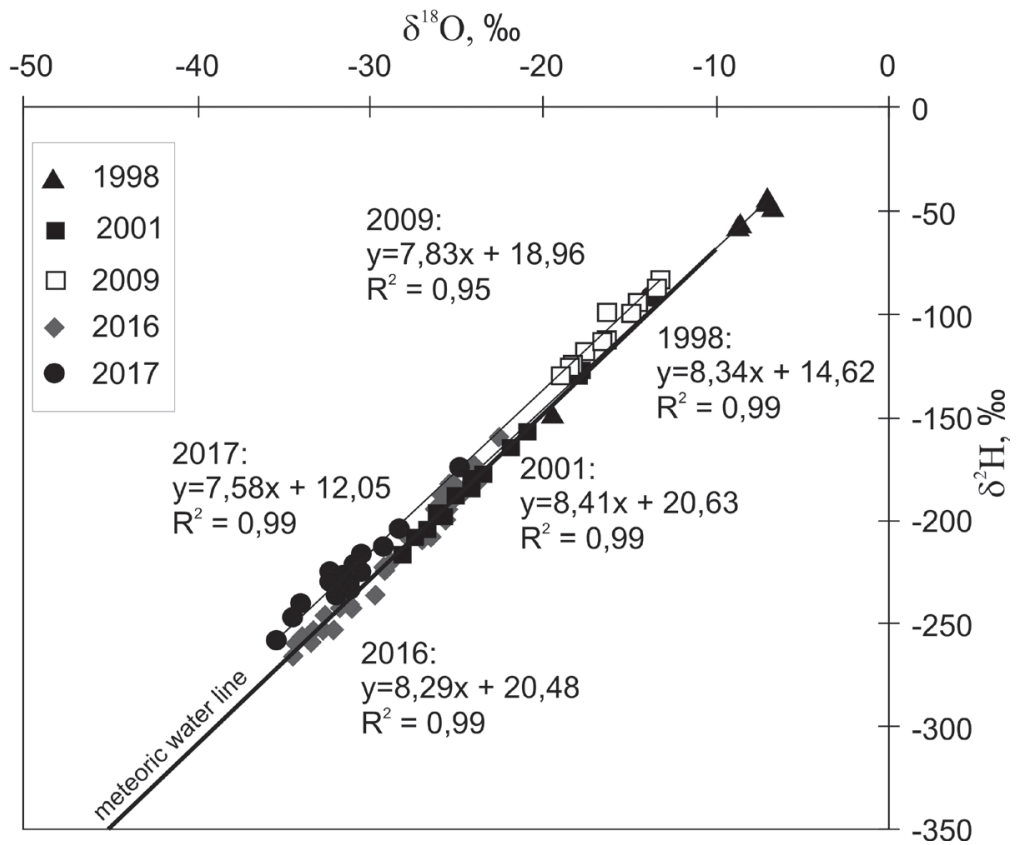

Fig. 3. The $\delta^{18} \mathrm{O}-\delta^{2} \mathrm{H}$ plot for all snow samples: 1998, 2001, 2009, 2016, 2017
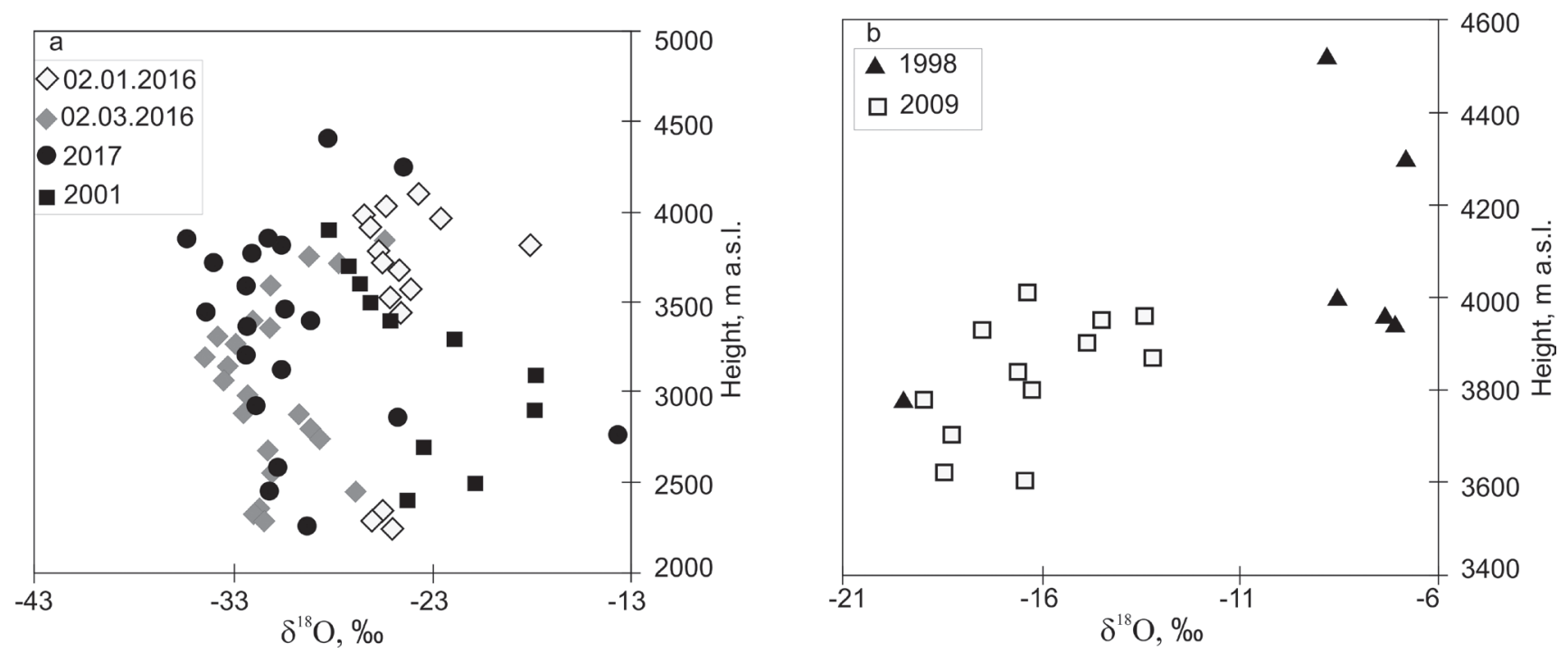

Fig. 4. The $\delta^{18} \mathrm{O}$ values in snow cover of Elbrus Mountain in winter (a) and summer season (b) 
Table 1. Deuterium excess of snow cover of Elbrus Mountain

\begin{tabular}{|c|c|c|c|c|}
\hline \multirow{2}{*}{ Year } & \multirow{2}{*}{ Type of snow } & mean & $\mathrm{d}_{\mathrm{exc}}$ \%o & \multicolumn{2}{|c|}{ max } \\
\cline { 3 - 5 } & Summer melted & 11 & 15 & 7 \\
\hline 1998 & Winter fresh & 11 & 14 & 9 \\
\hline 2001 & Summer fresh & 22 & 32 & 18 \\
\hline 2009 & Winter fresh & 12 & 22 & 2 \\
\hline 2016 & Winter fresh & 24 & 33 & 17 \\
\hline
\end{tabular}

cipitation fell at low temperatures and low relative humidity (Pang et al. 2011). On the contrary, the higher $d_{\text {exc }}$ values during the winter months are caused by the lower relative humidity at the oceanic source regions. The inverse trend for $d_{\text {exc }}$ values in summer precipitation may occur in regions where the atmospheric water vapor dominates due to moisture evaporation from continental basins (Schotterer et al. 1993; Schotterer et al. 1997).

We consider separately the surface snow (which lay after falling out for some time and was subjected to various processes: re-deposition, sublimation, melting, drifting, etc.) and fresh newly deposited snow, which was sampled either immediately after snowfall or the next day after.

\section{Newly deposited (fresh) snow}

In fresh snow sampled on 27 and 28 January 2017, the $\delta^{18} \mathrm{O}$ values vary from -24.84 to $-34.46 \%$, the $\delta^{2} \mathrm{H}$ from -173.2 to $-247.9 \%$ (Table 2). Regardless of the date of selection, all samples are in the altitude range of 2256-3850 $\mathrm{m}$ a.s.l. Practically, there is no clear relationship between the $\delta^{18} \mathrm{O}$ and $\delta^{2} \mathrm{H}$ values and altitude (Fig. 5). However, some weak trend to decreasing $\delta^{18} \mathrm{O}$ values with altitude can be identified by calculating the difference between isotope content at 2256 $\mathrm{m}$ a.s.l. and $3850 \mathrm{~m}$ a.s.I. It gives the gradient to be $-0.32 \% 0$ $\delta^{18} \mathrm{O} / 100 \mathrm{~m}$.

On 3 February 2016, the $\delta^{18} \mathrm{O}$ values increased from $-34.5 \%$ to $-25.5 \%$ in fresh snow between 2287 and 3836 $\mathrm{m}$ a.s.l., the lowest $\delta^{18} \mathrm{O}$ values were obtained near $3000 \mathrm{~m}$ a.s.l. (Fig. 6). It was found that there is a clear inverse altitudinal isotope effect between 4000 and 3000 a.s.l. with a gradient of $\delta^{18} \mathrm{O}=+1.04 \%$ o/100 m (Table 2). Below $3000 \mathrm{~m}$ a.s.l., the $\delta^{18} \mathrm{O}$ and $\delta^{2} \mathrm{H}$ values distributed randomly which could be attributed to the lower boundary of air mass or turbulent mixing inside of it.

In August 2009, fresh snow showed weak positive isotope trend with altitude with a low statistical significance (Fig. 7).

In 2001, the altitudinal isotope effect has been observed above $3000 \mathrm{~m}$ in fresh snow with gradient of $\delta^{18} \mathrm{O}-1.3 \% \mathrm{o} / 100$ $\mathrm{m}$ and $\delta^{2} \mathrm{H}-11.1 \% 0 / 100 \mathrm{~m}$ (at $3100 \mathrm{~m} \delta^{18} \mathrm{O}=-17.81 \%$, $\delta^{2} \mathrm{H}$ $=-128.1 \%$, at $3900 \mathrm{~m} \delta^{18} \mathrm{O}=-28.24 \%$, $\delta^{2} \mathrm{H}=-217.1 \%$, see Fig. 6).

Simultaneous temperature measurements on the southern slope of Elbrus in the altitude range of 2355-3853 $\mathrm{m}$ showed temperature drop with altitude for different types of weather in the 2016/17 season (Table 3 ).
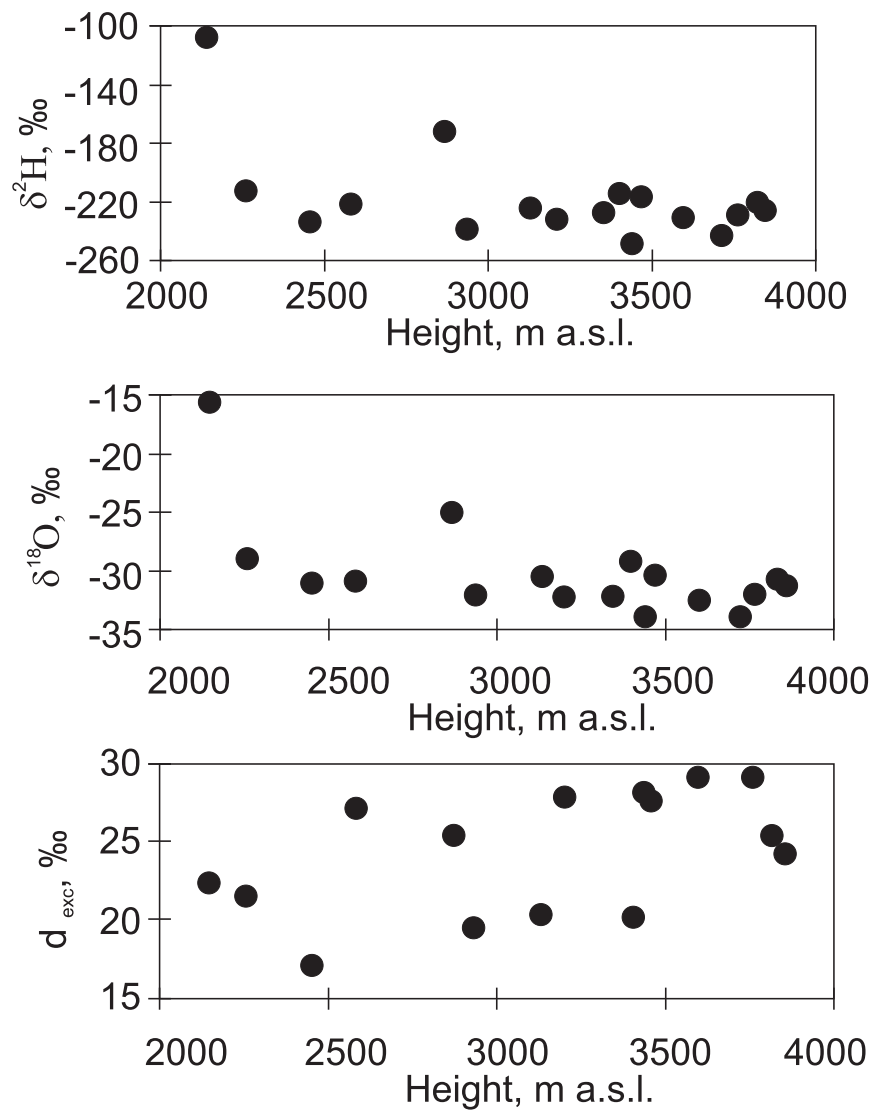

Fig. 5. The altitudinal effect on $\delta^{18} \mathrm{O}, \delta^{2} \mathrm{H}$ and $\mathrm{d}_{\text {exc }}$ for fresh snow in 27 January 2017 
Table 2. The altitudinal distribution of $\delta^{18} \mathrm{O}$ and $\delta^{2} \mathrm{H}$ values in fresh snow on Elbrus in 2016 and 2017

\begin{tabular}{|c|c|c|c|c|c|}
\hline Sample ID & Height, m & $\delta^{18} \mathrm{O}, \% 0$ & $\Delta \delta^{18} \mathrm{O}, \% 0 / 100 \mathrm{~m}$ & $\delta^{2} \mathrm{H}, \%$ & $\mathrm{~d}_{\text {exc' }} \% 0$ \\
\hline \multicolumn{6}{|c|}{03.02 .2016} \\
\hline E19c & 3836 & -25.5 & \multirow{12}{*}{+1.04} & -191 & 12.68 \\
\hline $\mathrm{E} 20 \mathrm{C}$ & 3747 & -29.2 & & -224 & 9.63 \\
\hline $\mathrm{E} 21 \mathrm{C}$ & 3705 & -27.7 & & -209 & 12.04 \\
\hline $\mathrm{E} 22 \mathrm{C}$ & 3588 & -31.1 & & -243 & 6.45 \\
\hline E23 C & 3457 & -34.4 & & -260 & 15.59 \\
\hline E24C & 3403 & -32.1 & & -242 & 14.87 \\
\hline $\mathrm{E} 26 \mathrm{C}$ & 3351 & -31.3 & & -237 & 12.96 \\
\hline E27 C & 3307 & -33.9 & & -257 & 14.51 \\
\hline E28 C & 3255 & -32.8 & & -253 & 10.02 \\
\hline E29c & 3197 & -34.5 & & -266 & 10.13 \\
\hline E30 & 3142 & -33.3 & & -253 & 13.43 \\
\hline E31 & 3064 & -33.5 & & -259 & 8.98 \\
\hline E32 & 2978 & -32.2 & \multirow{4}{*}{ Not pronounced } & -253 & 5.18 \\
\hline E35 & 2353 & -31.8 & & -242 & 12.11 \\
\hline E34 & 2321 & -32.1 & & -242 & 14.71 \\
\hline E33 & 2287 & -31.6 & & -241 & 11.32 \\
\hline \multicolumn{6}{|c|}{04.02 .2016} \\
\hline E36 C & 2908 & -32.2 & \multirow{8}{*}{ Not pronounced } & -252 & 6.12 \\
\hline E37 C & 2462 & -27.0 & & -209 & 6.51 \\
\hline E38 c & 2884 & -32.6 & & -247 & 14.26 \\
\hline E39c & 2548 & -31.2 & & -236 & 13.57 \\
\hline $\mathrm{E} 40 \mathrm{C}$ & 2872 & -29.7 & & -236 & 1.80 \\
\hline E41c & 2796 & -29.2 & & -222 & 11.61 \\
\hline $\mathrm{E} 42 \mathrm{C}$ & 2744 & -28.7 & & -219 & 10.83 \\
\hline $\mathrm{E} 43 \mathrm{C}$ & 2665 & -31.3 & & -241 & 9.12 \\
\hline \multicolumn{6}{|c|}{27.01 .2017} \\
\hline E1-2017 & 3850 & -31.28 & \multirow{3}{*}{ Not pronounced } & $-225,9$ & 24.3 \\
\hline E7-2017 & 3820 & -30.65 & & -220 & 25.2 \\
\hline E2-2017 & 3764 & -32.12 & & -228 & 28.96 \\
\hline E9-2017 & 3716 & -33.97 & \multirow{14}{*}{-0.32} & -241.6 & 30.16 \\
\hline E3-2017 & 3598 & -32.47 & & -230.8 & 28.96 \\
\hline E4-2017 & 3468 & -30.47 & & -216.5 & 27.26 \\
\hline E15-2017 & 3443 & -34.46 & & -247.9 & 27.78 \\
\hline E5-2017 & 3400 & -29.15 & & -213 & 20.2 \\
\hline E8-2017 & 3351 & -32.31 & & -225.2 & 33.28 \\
\hline E6-2017 & 3205 & -32.31 & & -230.8 & 27.68 \\
\hline E16-2017 & 3130 & -30.61 & & -224.5 & 20.38 \\
\hline E10-2017 & 2931 & -32.02 & & -236.8 & 19.36 \\
\hline E11-2017 & 2865 & -24.84 & & -173.2 & 25.52 \\
\hline E13-2017 & 2579 & -30.94 & & -220.3 & 27.22 \\
\hline E14-2017 & 2454 & -31.24 & & -232.9 & 17.02 \\
\hline E18-2017 & 2256 & -29.28 & & -212.7 & 21.54 \\
\hline E19-2017 & 2145 & -15.63 & & -102.7 & 22.34 \\
\hline
\end{tabular}



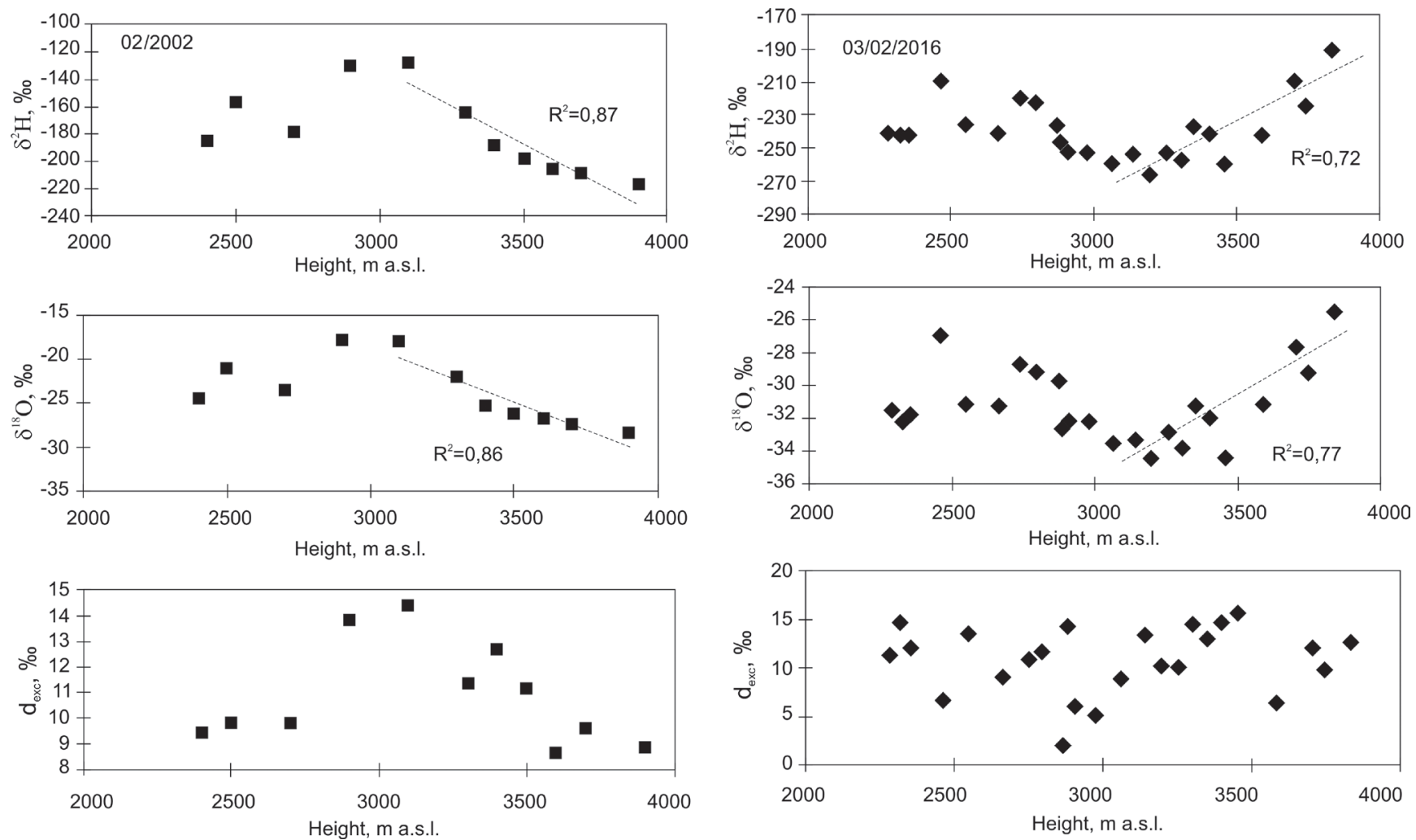

Fig. 6. The altitudinal effect on $\delta^{18} \mathrm{O}, \delta^{2} \mathrm{H}$ and $\mathrm{d}_{\mathrm{exc}}$ for fresh snow in 8 February 2001 and 3 February 2016
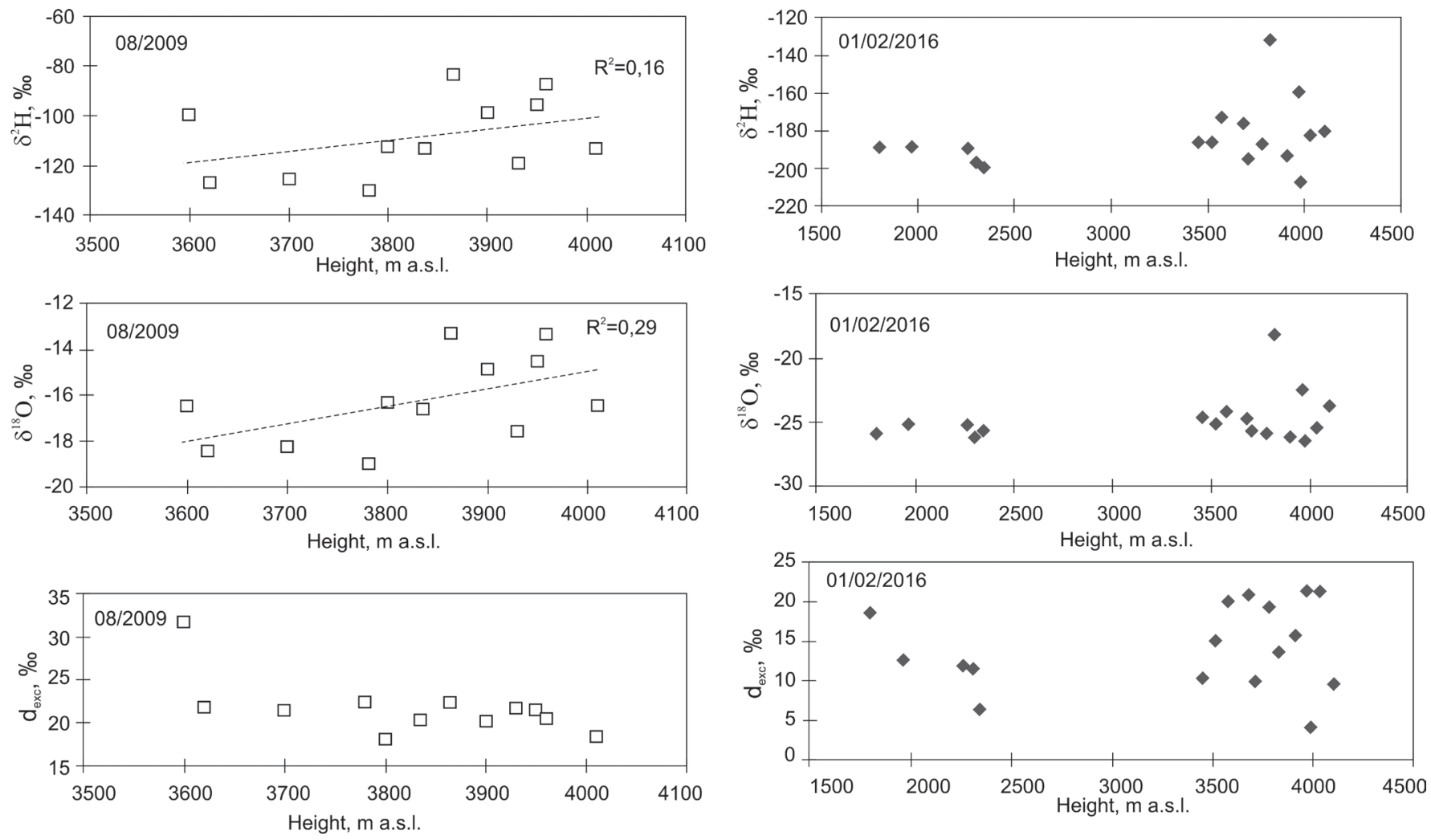

Fig. 7. The altitudinal effect on $\delta^{18} \mathrm{O}, \delta^{2} \mathrm{H}$ and $\mathrm{d}_{\mathrm{exc}}$ for fresh snow in August, 2009 and for surface snow 1 February, 2016

These values mean that for the snow samples of 2001, in which the altitude isotope effect is pronounced (from 2900 to $3900 \mathrm{~m}$ a.s.I.), the relationship coefficient $\delta^{18} \mathrm{O}$ with $\mathrm{T}$ is in the range from $0.55 \% /{ }^{\circ} \mathrm{C}$ to $0.76 \% /{ }^{\circ} \mathrm{C}$ (based on Table 3 data for different types of weather). This corresponds to the Rayleigh model of equilibrium isotope fractionation.

The decrease of $d_{\text {exc }}$ values with altitude was revealed (see Fig 6). Such decreasing d values during snowfall contradicts other model calculations (Jouzel and Merlivat 1984;
Ciais and Jouzel 1991) and field observations (Vasil'chuk et al. 2005).

\section{Surface snow}

Snow sampled on February 1, 2016, in the range of 1900 $m-4100 m$ a.s.l. is characterized by insignificant isotope variations (see Fig. 7). The possible reasons are: 1) the formation of isotope composition of snow at single condensation level from extensive cloud; 2 ) the initial isotope signal of the snow may 
be modified by processes of drifting or wind erosion. In the ablation season of 1998, the residual surface melted snow had the highest $\delta^{18} \mathrm{O}$ values from -6.82 to $-8.79 \%$ and $\delta^{2} \mathrm{H}$ from -41.9 to $-57.0 \%$ (see Fig. 4 , b). That probably was a result of spring-summer snow accumulation modified by sublimation and partial melting. The lower value at $3780 \mathrm{~m}$ a.s.l. indicates partial melting of surface snow and exposure of winter snow.

The absence of altitudinal isotope effect can be explained by the fact that snow-bearing air masses undergo no smallscale orographic uplift and secondly that the source and the trajectory of air masses are essential to the average isotopic content (Moran et al. 2007).

\section{Snow pits}

The mean values of $\delta^{18} \mathrm{O}$ for two snow pits in January 2017 at $2332 \mathrm{~m}$ and $3345 \mathrm{~m}$ a.s.l. were $-26.4 \%$ o, $-24.8 \%$ and the values for $\delta^{2} \mathrm{H}$ were $-189.7 \%$, $-174.8 \%$, respectively. While the mean $\delta^{18} \mathrm{O}$ and $\delta^{2} \mathrm{H}$ values in snow pit at a lower altitude are more negative than the values at a higher altitude (Fig. 8). In the pit at $2332 \mathrm{~m}$, the upper horizon is formed by snow with low values of $\delta^{18} \mathrm{O}(-29.4 \%)$ and $\delta^{2} \mathrm{H}(-215.4 \%)$, this is clearly freshly fallen January snow, in other snow horizons the $\delta^{18} \mathrm{O}$ and $\delta^{2} \mathrm{H}$ values are close to a uniform.
Similar values of $\delta^{18} \mathrm{O}$ and $\delta^{2} \mathrm{H}$ were obtained in the middle snow horizons at $3345 \mathrm{~m}$ a.s.l., while the lower horizon here is characterized by relatively high values (see Fig. 8), indicating the accumulation and preservation of snow, which was fallen most probably in autumn.

\section{Interpretation}

In fresh snow in February 2016, the most negative values of $\delta^{18} \mathrm{O}$ from -31.3 to $-34.4 \%$ in the range of $3064-$ $3457 \mathrm{~m}$ a.s.l. (Table 2) are extreme for Elbrus, especially for elevation below $4000 \mathrm{~m}$ a.s.l. Snow pit and firn core isotope records obtained at $5115 \mathrm{~m}$ a.s.l. (Kutuzov et al. 2013) show a clear season variation from $-27 \%$ to $-5.5 \%$ for $\delta^{18} \mathrm{O}$ values. Extremely negative isotope values in fresh snow of 2016 may be explained by drying of the air mass. The evolution of the isotope composition of water vapor during condensation and rainout from an idealized air mass is commonly modeled as a Rayleigh distillation process. The late stages of rainout are associated with rapid decreases of $\delta^{18} \mathrm{O}$ values in precipitation and in vapor. The rate of decrease of $\delta^{18} \mathrm{O}$ values also increases exponentially as the air mass dries out, and is greater at lower temperatures (Moran et al. 2007).

Table 3. Measured air temperature on the southern slope of Elbrus in 2017

\begin{tabular}{|c|c|c|c|c|}
\hline $\begin{array}{c}\text { Date and type of the } \\
\text { weather } \\
\text { Height a.s.l. }\end{array}$ & $\begin{array}{c}\text { 30/01/2017 } \\
\text { Cloudy with clearings, } \\
\text { overhead fog }\end{array}$ & $\begin{array}{c}31 / 01 / 20017 \\
\text { Clear, little } \\
\text { cloudy }\end{array}$ & $\begin{array}{c}\text { 4/02/2017 } \\
\text { Clear, in the } \\
\text { morning cloudy }\end{array}$ & $\begin{array}{c}\text { 5/02/2017 } \\
\text { Cloudy with clearings, the bottom } \\
\text { of the sun, above the fog }\end{array}$ \\
\hline 2355 & -15 & -18 & -4 & -2 \\
\hline 2934 & -22 & -21 & -13 & -12 \\
\hline 3465 & -27 & -28 & -15 & -14 \\
\hline 3853 & -23 & -0.53 & -0.734 & -0.80 \\
\hline
\end{tabular}
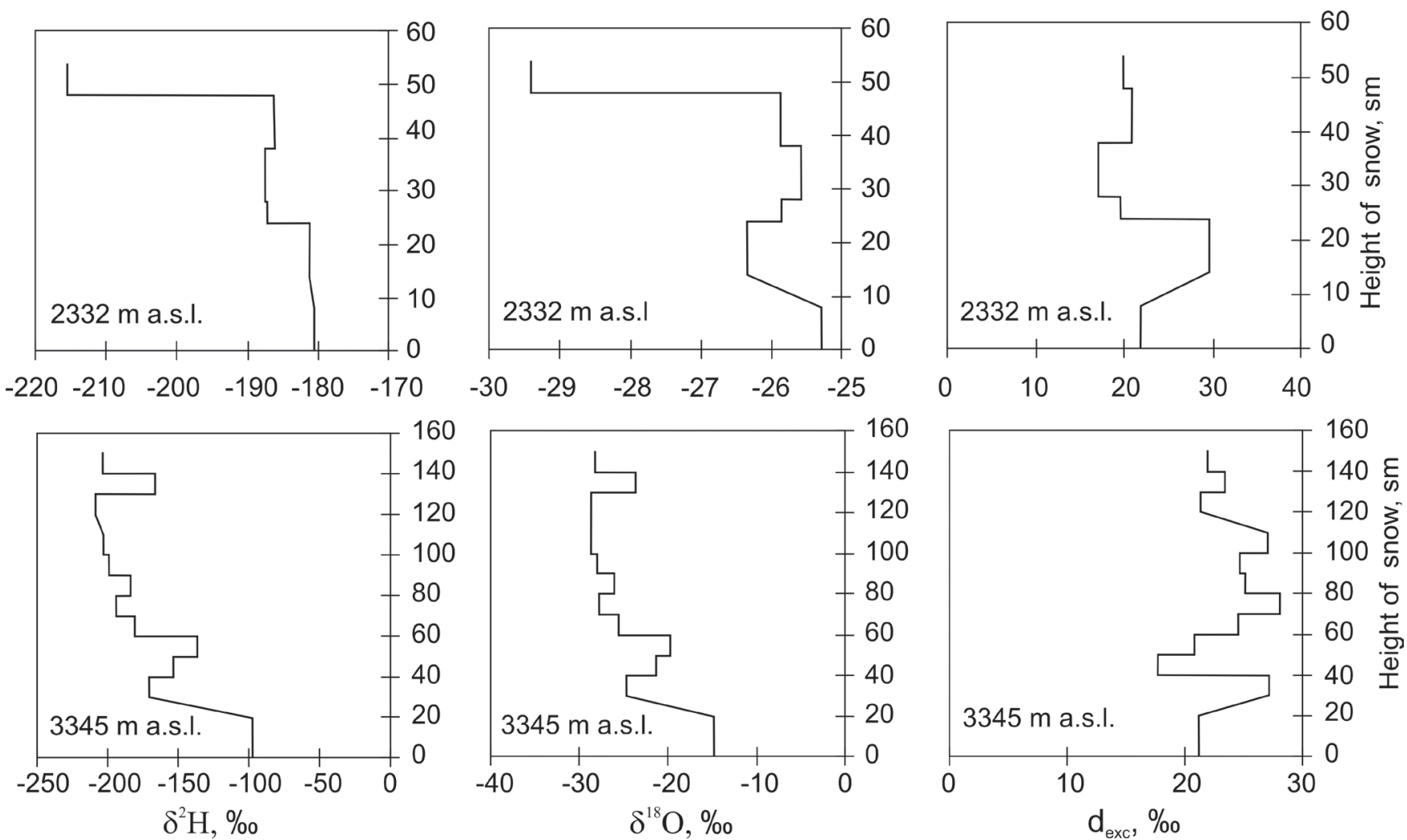

Fig. 8. The values of $\delta^{18} \mathrm{O}, \delta^{2} \mathrm{H}$ and $\mathrm{d}_{\text {exc }}$ in snow pits at 2332 and $3345 \mathrm{~m}$ a.s.l. 
In any case, we can not ignore the empirical data obtained for snow on 3 February, even if the isotope values distribution was not described by any model.

The formation of an altitude isotopic effect is not always associated with local conditions like a windward / leeward slope, temperature, etc. The absence of altitude effect is often explained by the fact that air masses do not follow the orographic uplift and, secondly, the source and trajectories of air masses, that could change pretty fast, are both important for the formation of isotope composition.

Moore et al. (2016) investigated the importance of nonlocal processes through the analysis of the synoptic scale circulation during a snowfall event at the summit of Mount Wrangell in south-central Alaska. During this event, there was over a 1-day period in which the local temperature was approximately constant, a change in $\delta^{18} \mathrm{O}$ values that exceeded half that normally seen to occur between summer and winter in the region. It may be suggested that a change in the source region for the snow that fell on Mount Wrangell during the event from the subtropical eastern Pacific to northeastern Asia.

In order to explain isotope signal in the sow collected on the 3rd of February, we suppose a simultaneous coming of one air mass to the mountain slope, but by two ways. Backward air masses trajectories to Mt. Elbrus are provided by NOAA using the HYSPLIT model (Draxler and Rolph 2011), calculated for the 3rd of February at 3000 and 5000 m showed one source and one path of moisture from the north. The most negative $\delta^{18} \mathrm{O}$ and $\delta^{2} \mathrm{H}$ values corresponded to 3064-3457 m a.s.l. range. One of the reasons for this distribution of $\delta^{18} \mathrm{O}$ and $\delta^{2} \mathrm{H}$ values in snow is the removal of a part of the snow from the summit zone to a height of $3000 \mathrm{~m}$. In this case, snow with low $\delta^{18} \mathrm{O}$ and $\delta^{2} \mathrm{H}$ values, deposited on summit is blown downward, forming a reverse altitude isotope effect. Another reason is that the altitude of $3000 \mathrm{~m}$ corresponds to the zone of maximum accumulation. Progressive precipitation leads to strong isotopic depletion of the remaining vapor and the last precipitation. It is obvious that the inverse high-altitude isotope effect is associated with these very negative values at an altitude of about $3000 \mathrm{~m}$.

In fresh snow sampled in 2017 with a weakly decreasing of $\delta^{18} \mathrm{O}$ and $\delta^{2} \mathrm{H}$ values with altitude, there is also a very slight increase of $d_{\text {exc. }}$. The main feature of the isotope signature of snow in 2017 is high d values reaching 33\% (see Table 1, Table 2). Backward HYSPLIT trajectories to Mt. Elbrus for the 26th of January 2017 at 3000 and 5000 m showed the source of moisture was the Mediterranean area. It is known that this region during the winter months due to low relative humidity over the sea is a source of precipitation with high deuterium excess (Gat and Carmi 1970).

In fresh snow sampled in 2001, there was a "classical" altitudinal isotope effect in precipitation due to orographic uplift of air masses and the related decrease in the condensation temperature (see Fig. 6).
When precipitation falls from air masses as they traverse topographic barriers, continued Rayleigh distillation on the lee slope should indeed produce an inverse relationship with altitude-lighter isotopic ratios with decreasing altitude. This would suggest a systematic altitudinal relationship that is the opposite of that which is observed on windward slopes, but an inverse relationship of this type is not well established or widely reported.

Poage and Chamberlain (2001) provide a compilation of observed $\delta^{18} \mathrm{O}$-elevation gradients from 68 different studies worldwide, with only two of these studies reporting $\delta^{18} \mathrm{O}$ depletion of precipitation with altitude. Ambiguous or inverse $\delta^{18} \mathrm{O}$-elevation relationships have been reported from eastern (lee) slopes in Sierra Nevada (Friedman and Smith 1970) and the Canadian Rockies (Grasby and Lepitski 2002). Complex altitudinal relationships are also evident in high alpine snow samples (Niewodnizański et al. 1981). This study indicates the necessity to further study the isotope variability of the snow cover to predict the isotopic composition of snowmelt water and to better understand the accumulation processes and the sources of snow in high mountains.

\section{CONCLUSIONS}

The results suggest that $\delta^{18} \mathrm{O}$-elevation gradients in fresh snow on south slope of Elbrus Mountain have similar values but opposite trends in different years and seasons. Above $3000 \mathrm{~m}$ in 2001, the $\delta^{18} \mathrm{O}$ values decreased with altitude by $-1.3 \%$ o/100 $\mathrm{m}\left(-11,1 \%\right.$ o $\left.\delta^{2} \mathrm{H} / 100 \mathrm{~m}\right)$, in 2016 , the $\delta^{18} \mathrm{O}$ values increased with altitude by $+1.04 \%$ o $/ 100 \mathrm{~m}\left(+8.76 \%\right.$ o $\delta^{2} \mathrm{H}$ $/ 100 \mathrm{~m}$ ).

In 2017, the relationship between the values of $\delta^{18} \mathrm{O}$ and $\delta^{2} \mathrm{H}$ with the altitude of the terrain is not clearly pronounced with a weakly decreasing $\delta^{18} \mathrm{O}$ values in an altitude range of 2256-3716 $\mathrm{m}$ a.s.l., there is also a very slight increase of $d_{\text {exc }}$. Such an uneven distribution of the isotope composition of snow with altitude in different seasons most likely is explained by various mechanisms of snow deposition - orographic uplift of the air mass along the slope or over-climbing through the main Caucasian ridge and considerable drift of dry snow on the slope.

Below $3000 \mathrm{~m}$, the disruption of $\delta^{18} \mathrm{O}$-elevation gradients has been attributed to post-depositional altering, wind movement, turbulent mixing of air masses or simultaneous coming of an air mass to the slope.

\section{ACKNOWLEDGEMENTS}

Researches are financially supported by Russian Foundation for Basic Research (grants RFBR № 16-05-00977 field research, 18-05-60272, isotope analyses and 18-05-60021, data compilation). 


\section{REFERENCES}

Ambach W., Eisner H. and Pessl K. (1972). Isotopic oxygen composition of firn, old snow and precipitation in alpine regions. Z. Gletscherk. Glazialgeol., 8, pp. 125-135.

Ciais P. and Jouzel J. (1994). Deuterium and oxygen-18 in precipitation: Isotopic model, including mixed cloud processes. J. Geoph. Res., 99(D8), pp. 16793-16803.

Dansgaard W. (1964). Stable isotopes in precipitation. Tellus, 16, pp. 436-468.

Dietermann N. and Weiler M. (2013). Spatial distribution of stable water isotopes in alpine snow cover. Hydrol. Earth Syst. Sci., 17, pp. 26057-2668.

Draxler R.R. and Rolph G.D. (2011). HYSPLIT (Hybrid Single-Particle Lagrangian Integrated Trajectory) Model access via NOAA ARL READY Website (http://ready.arl.noaa.gov/HYSPLIT.php). NOAA Air Resources Laboratory, Silver Spring, MD.

Gat J.R. and Carmi I. (1970). Evolution of the isotopic composition of atmospheric waters in the Mediterranean Sea Area. Journal of Geophysical Research, 75, pp. 3039-3048.

Grasby S.E. and Lepitzki D.A.W. (2002). Physical and chemical properties of the Sulphur Mountain thermal springs, Banff National Park, and implications for endangered snails. Canadian Journal of Earth Sciences, 39, pp. 1349-1361.

He Y., Pang H., Theakstone W.H., Zhang D., Lu A., Song B., Yuan L. and Ning B. (2006). Spatial and temporal variation of oxygen isotopes in snowpacks and glacial runoff in different types of glacial area in western China. Annals of Glaciology, 43, pp. $269-274$.

Holdworth G., Fogarasi S. and Krouse H.R. (1991). Variation of the stable isotopes of water with altitude in the Saint Elias Mountains of

Canada. J. Geophysical Res., 96(4), pp. 7483-7494.

Holobâcă J-H. (2016). Recent retreat of the Elbrus glacier system. Journal of Glaciology, 62(231), pp. 94-102.

Friedman I. and Smith G. (1970). Deuterium content of snow cores from Sierra Nevada area. Science, 169, pp. 467-470.

Jouzel J. and Merlivat L. (1984). Deuterium and oxygen-18 in precipitation: modeling of the isotopic effects during snow formation. Journal Geophysical Res., 89(7), pp. 11749-11757.

Judy C., Meiman J.R. and Friedman I. (1970). Deuterium variations in an annual snowpack. Water Resour. Res., 6, pp. 125-129.

Kang S., Kreutz K.J., Mayewski P.A., Qin D. and Yao T. (2002). Stable-isotopic composition of precipitation over the northern slope of the central Himalaya. Journal of Glaciology, 48(163), pp. 519-526.

Kozachek A., Mikhalenko V., Masson-Delmotte V., Ekaykin A., Ginot P., Kutuzov S., Legrand M., Lipenkov V. and Preunkert S. (2017). Largescale drivers of Caucasus climate variability in meteorological records and Mt Elbrus ice cores. Climate of the Past, 13, pp. 473-489.

Königer P., Hubbart J.A., Link T. and Marshall J.D. (2008). Isotopic variation of snow cover and streamflow in response to changes in canopy structure in a snow-dominated mountain catchment. Hydrol. Process., 22, pp. 557-566.

Kutuzov S., Shahgedanova M., Mikhalenko V., Ginot P., Lavrentiev I. and Kemp S. (2013). High-resolution provenance of desert dust deposited on Mt. Elbrus, Caucasus in 2009-2012 using snow pit and firn core records. The Cryosphere, 7, pp. 1481-1498.

Merlivat L. and Jouzel J. (1979). Global climatic interpretation of the deuterium oxygen 18 relationship for precipitation. J. Geophys. Res., 84, pp. 5029-5033.

Mikhalenko V., Sokratov S., Kutuzov S., Ginot P., Legrand M., Preunkert S., Lavrentiev I., Kozachek A., Ekaykin A., Faïn X., Lim S., Schotterer U., Lipenkov V. and Toropov P. (2015). Investigation of a deep ice core from the Elbrus western plateau, the Caucasus, Russia. The Cryosphere, 9, pp. 2253-2270.

Moore G.W.K., Field R. and Benson C.S. (2016). Impact of Source Region on the $\delta^{18} \mathrm{O}$ Signal in Snow: A case study from Mount Wrangell, Alaska. Journal of Hydrometeorology, 17, pp. 139-151.

Moran T.A., Marshall S.J., Evans E.C. and Sinclair K.E. (2007). Altitudinal gradients of stable isotopes in lee-slope precipitation in the

Canadian Rocky Mountains. Arct. Antarct. Alpine Res., 39(3), pp. 455-467.

Moser H. and Stichler W. (1970). Deuterium measurements on snow samples from the Alps. In Isotope Hydrology (Proceedings of a

Symposium on Use of Isotopes in Hydrology), IAEA, Vienna, 43-57.

Moser H. and Stichler W. (1974). Deuterium and oxygen-18 contents as an index of the properties of snow covers. In Snow Mechanics

(Proceedings of the Grindelwald Symposium, Switzerland, April 1974), IAHS Publ., 114: 122-135.

Niewodnizański J., Grabczak J., Barański L. and Rzepka J. (1981). The altitude effect on the isotopic composition of snow in high mountains. Journal of Glaciology, 27(95), pp. 99-111.

Pang Z., Kong Y., Froehlich K., Huang T., Yuan L., Li Z. and Wang F. (2011). Processes affecting isotopes in precipitation of an arid region. Tellus, 63(3), pp. 352-359.

Poage M.A. and Chamberlain C.P. (2001). Empirical relationships between elevation and the stable isotope composition of precipitation and surface waters: considerations for studies of paleoelevation change. American Journal of Science, 31, pp. 1-15.

Raben P. and Theakstone W.H. (1994). Isotopic and ionic changes in a snow cover at different altitudes: observations at Austre Okstindbreen in 1991. Ann. Glaciol., 19, pp. 85-91.

Risi C., Bony S., Vimeux F., Chong M. and Descroix L. (2010). Evolution of the stable water isotopic composition of the rain sampled along Sahelian squall lines. Q. J. R. Meteorol. Soc., 136(s1), pp. 227-242.

Rototaeva O.V., Nosenko G.A., Tarasova L.N. and Khmelevskoy I.F. (2006). General characteristics of glacierization of the north slope of the Gteater Caucasus). In: V.M. Kotlyakov, ed. Glaciation in North and Central Eurasia at Present Time. Moscow: Nauka Publ. House, pp. 141-144. (in Russian).

Rozanski K. and Araguas-Araguas L. (1995). Spatial and temporal variability of stable isotope composition over the South American continent. Bull. Inst. Fr. Etud. Andin., 24, pp. 379-390.

Schotterer U., Fröhlich K., Stichler W. and Trimbom P. (1993). Temporal variations of oxygen-18 and deuterium excess in alpine regions of Switzerland. In: Isotope Techniques in the Study of Past and Current Environmental Changes in the Hydrosphere and the Atmosphere (Proc. Symp. Int. Atomic Energy Agency, Vienna), pp. 53-64.

Schotterer U., Gäggeler H.W., Fröhlich K., Sandjordj S. and Stichler W. (1997). Isotope records from Mongolian and alpine ice cores as climate indicator. Climatic Change, 36, pp. 519-530.

Shahgedanova M., Kutuzov S., White K.H., and Nosenko G. (2013). Using the significant dust deposition event on the glaciers of Mt. Elbrus, Caucasus Mountains, Russia on 5 May 2009 to develop a method for dating and "provenancing" of desert dust events recorded in snow pack. Atmos. Chem. Phys., 13, pp. 1797-1808.

Siegenthaler U. and Oeschger H. (1980). Correlation of O-18 in precipitation with temperature and altitude. Nature, 285, pp. 314-317. Sokratov S.A. and Golubev V.N. (2009). Snow isotopic content change by sublimation. Journal of Glaciology, 55, pp. $823-828$. 
Stichler W., Schotterer U., Fröhlich K., Ginot P., Kull C., Gäggeler H. and Pouyaud B. (2001). Influence of sublimation on stable isotope records recovered from high-altitude glaciers in the tropical Andes. J. Geophys. Res., 19, pp. 22613-22620.

Tielidze L.G. and Wheate R.D. (2017). The Greater Caucasus Glacier Inventory (Russia/Georgia/Azerbaijan). The Cryosphere Discuss., doi:10.5194/tc-2017-48. 27 p.

Vasil'chuk Y.K. and Chizhova J.N. (2010). Altitude gradient of $\delta^{18} \mathrm{O}$ and $\delta D$ in precipitation and snow cover in high mountain. Earth Cryosphere, 14(1), pp. 13-21 (in Russian).

Vasil'chuk Y.K., Chizhova J.N., Budantseva N.A. and Mukhina J.S. (2010). Rapid reduction of the glacier Big Azau, Elbrus on stable climatic conditions and risks appearing in this case. Georisk, 2, pp. 16-29 (in Russian).

Vasil'chuk Y.K., Chizhova J.N. and Budantseva N.A. (2006). Isotope composition of Bolchoy Azau glacier tongue, Elbrus. Earth Cryosphere, 1(10), pp. 56-68 (in Russian).

Vasil'chuk Yu.K., Chizhova Ju.N. and Papesch W. (2005). Trend of isotope composition of a separate winter snowfall in northeastern Europe. Earth Cryosphere, 9(3), pp. 81-87. (in Russian).

Volodicheva N.A. (2002). The Caucasus. In: M. Shahgedanova, ed. The Physical Geography of Northern Eurasia, Oxford: Oxford University Press, pp. 350-376.

Yamanaka T. and Yamada Y. (2017). Regional Assessment of Recharge Elevation of Tap Water Sources Using the Isoscape Approach. Mountain Research and Development, 37(2), pp. 198-205.

Zolotarev Y.A. and Kharkovets Y.G. (2010). Evolution of the Elbrus glaciation since the mid XIX century under changing climate. Key findings of the glacio-cartographical monitoring. Geogr. Environ. Sustainability, 2, pp. 13-32.

Received on May $31^{\text {th }}, 2018$

Accepted on January $21^{\text {th }}, 2020$ 